\title{
Pengaruh Pola Asuh Orang Tua Terhadap Hasil Belajar Matematika Siswa
}

\section{Shintia Pratini $\mathbf{T}^{1^{*}}$, Sripatmi ${ }^{2}$, Syahrul Azmi ${ }^{2}$, Ketut Sarjana ${ }^{2}$}

\author{
${ }^{1}$ Mahasiswa Pendidikan Matematika, FKIP, Universitas Mataram, Mataram \\ ${ }^{2}$ Dosen Pendidikan Matematika, FKIP, Universitas Mataram, Mataram
}

shintiatya02@gmail.com

Diterima: 16-12-2021; Direvisi: 30-12-2021; Dipublikasi: 30-12-2021

\begin{abstract}
The purpose of this study was to determine the type of parenting that affects mathematics learning outcomes and to determine the criteria for mathematics learning outcomes for class XI students of Public Vocational Secondary School 3 Mataram in the 2019/2020 school year. This type of research is ex post facto research with descriptive and quantitative statistical approaches. Determination of the sample is done by proportionate purposive sampling technique by taking representatives of each class to be sampled, after taking $20 \%$ of the population, a sample of 131 students is obtained. The type of parenting that is applied by parents is determined based on the highest score on the parenting questionnaire for each whole item statement for each parenting. Based on the results of data analysis using descriptive statistical techniques, there are 12 students with authoritarian parenting types, 44 students with permissive parenting types, and 75 students with authoritative parenting. Student mathematics learning outcomes for each parenting are mostly in the very low category. Based on the results of the hypothesis test, the value of $t$ calculated for each parenting, obtained from authoritarian, permissive, and authoritative parenting respectively $0.83,-1.16$, and 3.63 , with a value of t_table is $2.02,2.23$, and 1.99. Thus, it can be seen that parenting patterns that affect the learning outcomes of students of class XI in SMK Negeri 3 Mataram are authoritative parenting, because the calculated value is greater than the value of $t$ table, which is $3,63>1.99$, with the influence of $15.32 \%$.
\end{abstract}

Keywords: effect; parenting; learning outcomes

\begin{abstract}
Abstrak
Tujuan penelitian ini adalah untuk mengetahui jenis pola asuh yang berpengaruh terhadap hasil belajar matematika dan untuk mengetahui kriteria hasil belajar matematika siswa kelas XI SMK Negeri 3 Mataram Tahun Pelajaran 2019/2020. Jenis penelitian yang digunakan adalah penelitian ex pos facto dengan pendekatan statistic deskriptif dan kuantitatif. Banyak sampel yang digunakan ialah 131 siswa yang diambil dengan menggunakan teknik proportionate purposive sampling. Jenis pola asuh yang diterapkan oleh orang tua ditentukan berdasarkan skor tertinggi tiap keseluruhan item pernyataan untuk masing-masing jenis pola asuh. Berdasarkan hasil analisis data dengan menggunakan teknik statistik deskriptif, terdapat 12 siswa dengan tipe pola asuh otoriter, 44 siswa dengan tipe pola asuh permissif, dan 75 siswa dengan pola asuh autoritatif. Hasil belajar matematika siswa untuk tiap-tiap pola asuh sebagian besar berada pada kategori sangat rendah. Berdasarkan hasil uji hipotesis, diperoleh nilai $t_{\text {hitung }}$ untuk tiap-tiap pola asuh, mulai dari pola asuh otoriter, permisif, dan autoritatif secara berturut-turut yaitu 0,83-1.16, dan 3.63, dengan nilai $t_{\text {tabel }}$ yaitu 2.02, 2.23, dan 1.99.Sehingga,
\end{abstract}


dapat diketahui bahwa pola asuh orang tua yang berpengaruh terhadap hasil belajar matematika siswa kelas XI SMK Negeri 3 Mataram adalah pola asuh autoritatif, karena nilait hitung lebih besar daripada niali $t$ tabel, yaitu $3.63>1.99$, dengan besar pengaruh yaitu $15.32 \%$.

Kata Kunci: pengaruh; pola asuh orang tua; hasil belajar

\section{PENDAHULUAN}

Dalam Undang-Undang Nomor 20 Tahun 2003 tentang Sistem Pendidkan Nasional (Pasal 37 Ayat 10) dinyatakan bahwa kurikulum pendidikan dasar dan menengah wajib memuat: pendidikan agama, pendidikan kewarganegaraan, bahasa, matematika, ilmu pengetahuan alam, ilmu pengetahuan sosial, seni dan budaya, pendidikan jasmani dan olahraga, keterampilan/kejuruan, dan muatan lokal. Dalam undang-undang tersebut, matematika menjadi salah satu mata pelajaran yang wajib pada setiap jenjang pendidikan dasar dan menengah. Menjadi mata pelajaran yang wajib pada setiap jenjang pendidikan membuat pelajaran matematika memiliki tingkat kesulitan yang berbeda-beda di setiap jenjangnya, karena semakin tinggi jenjang pendidikan maka tingkat kesulitannya juga akan semakin bertambah, karena materi yang dipelajari semakin luas dan semakin banyak.

Setiap pembelajaran tentunya memiliki tujuan. Untuk mengetahui berhasil atau tidaknya tujuan dari suatu pembelajaran, maka yang perlu diperhatikan adalah hasil belajarnya. Hasil belajar adalah sejumlah pengalaman yang diperoleh siswa yang mencakup ranah kognitif, apektif, dan psikomotorik. Belajar tidak hanya tentang penguasaan konsep teori mata pelajaran saja, tetapi juga penguasaan kebiasaan, persepsi, kesenangan, minat-bakat, jenis-jenis keterampilan, cita-cita, keinginan, dan harapan (Slameto, 2015). Tuntas atau tidaknya seorang siswa dalam belajar, dapat dilihat dari nilai yang diperoleh. Misalnya dari nilai ulangan harian, Penilaian Tengah Semester (PTS), atau pun Penilaian Akhir Semester (PAS). Jika nilai yang diperoleh berhasil mencapai atau melebihi Kriteria Ketuntasan Minimum (KKM), maka siswa tersebut dapat dikatakan tuntas dalam belajar.

Di SMK Negeri 3 Mataram, khususnya kelas X masih banyak siswa yang belum tuntas dalam belajar, karena dari 654 siswa, hanya ada 23 siswa yang tuntas dalam Penilaian Tengah Semester (PTS), selain itu semua siswa memperoleh hasil belajar di bawah KKM. Hasil belajar dapat dipengaruhi oleh berbagai faktor, baik itu berasal dari siswa (internal), maupun dari luar diri siswa (eksternal). Faktor internal yang dapat mempengaruhi hasil belajar bisa berupa motivasi, minat, serta rasa ingin tahu. Faktor eksternal yang dapat mempengaruhi hasil belajar yaitu faktor lingkungan, baik lingkungan sekolah, keluarga, dan masyarakat. Salah satu faktor eksternal yang mempengaruhi hasil belajar siswa ialah lingkungan keluarga, khususnya orang tua. Karena, ketika anak berada di rumah, orang tua bisa saja menjadi guru kedua bagi mereka. 
Berdasarkan wawancara dengan salah satu guru matematika kelas X SMK Negeri 3 Mataram, guru pamong pada saat melaksanakan Program Pengalaman Lapangan (PPL) diperoleh bahwa hasil belajar siswa dapat dipengaruhi oleh pola asuh atau bagaimana orang tua berinteraksi dengan anak di rumah. Karena, ada anak yang selalu diingatkan untuk belajar, dibantu menjelaskan pelajarannya di rumah, bahkan ada pula anak yang tidak dipedulikan tentang belajarnya sama sekali. Selain itu, ada pula anak yang dituntut untuk mendapatkan nilai yang tinggi, padahal sebenarnya anak tersebut tidak mampu memperoleh nilai yang tinggi. Sehingga, cara yang dilakukan oleh orang tua dalam membimbing dan mendidik anaknya, diduga dapat berpengaruh terhadap hasil belajarnya. Jika dalam membimbing dan mendidik orang tua selalu berusaha berinteraksi dengan anaknya, seperti berdiskusi tentang apa yang dipelajari, kesulitan apa saja yang dialami selama pembelajaran di sekolah, bahkan membantu anak untuk memahami materi ketika belajar di rumah, hal tersebut dapat membuat anak lebih giat lagi dalam belajar. Sehingga, mereka akan terus berlatih, mengulang kembali materi yang dijelaskan oleh guru serta mengerjakan tugas tepat waktu. Hal tersebut membuat siswa mampu memahami materi dengan lebih baik sehingga dapat memperoleh hasil belajar yang memuaskan.

Pola asuh orang tua adalah keseluruhan interaksi orang tua dan anak, dimana orang tua yang memberikan dorongan bagi anak dengan mengubah tingkah laku, pengetahuan, dan nilai-nilai yang dianggap paling tepat bagi orang tua, agar anak bisa mandiri, tumbuh serta berkembang secara sehat dan optimal, memiliki rasa percaya diri, memiliki sifat rasa ingin tahu, bersahabat, dan berorientasi dengan sukses (Tridhonanto, 2014). Secara garis besar, terdapat tiga tipe pola asuh orang tua terhadap anaknya yaitu pola asuh otoriter, autoritatif, dan pola asuh demokratis. Menurut Susmeini ,"Tipe-tipe pola asuh tersebut akan tercermin pada tingkah laku siswa dalam belajar" (Dasmo, 2011). Dalam menerapkan pola asuh, terdapat beberapa hal yang dapat mempengaruhinya, seperti pengalaman masa lalu yang berhubungan erat dengan pola suh atau pun sikap orang tua mereka, nilai-nilai yang dianut orang tua, tipe kepribadian dari orang tua, kehidupan perkawinan orang tua, serta alasan orang tua mempunyai anak (Gunarsa, 2006).

Berdasarkan uraian di atas, peneliti tertarik untuk melakukan penelitian di SMK Negeri 3 Mataram khususnya di kelas XI, dengan judul penelitian yaitu "Pengaruh Pola Asuh Orang Tua terhadap Hasil Belajar Matematika Siswa Kelas XI SMK Negeri 3 Mataram Tahun Pelajaran 2019/2020.”

\section{METODE PENELITIAN}

Jenis penelitian ini adalah penelitian ex post facto, dengan pendekatan deksriptif kuantitatif. Variabel penelitian terdiri dari variabel bebas (pola asuh orang tua) dan variabel terikat (hasil belajar matematika). Populasi penelitian adalah sebanyak 654 siswa, dengan jumlah sampel yang digunakan yaitu sebanyak 131 siswa, yang diambil $20 \%$ dari populasi kemudian dilanjutkan dengan menggunakan teknik proportionate purposive sampling. 
Teknik pengumpulan data yang digunakan dalam penelitian ini adalah menggunakan angket dan soal tes, yang dianalisis dengan menggunakan teknik statistik deskriptif dan statistik inferensial. Statistik deskriptif dikenakan pada instumen hasil belajar matematika. Statistik inferensial yang digunakan adalah analisis regresi sederhana yang kemudian dilanjutkan dengan uji t untuk melihat apakah tiap-tiap pola asuh orang tua berpengaruh secara signifikan terhadap hasil belajar matematika siswa.

Berdasarkan data hasil penelitian, dengan skor maksimum ideal yang digunakan adalah 100. Sedangkan skor minimum ideal yang digunakan adalah Kriteria Ketuntasan Minimal (KKM) Matematika di SMK Negeri 3 Mataram, yaitu 60. Sehingga didapatkan hasil perhitungan sebagai berikut:

$$
\begin{aligned}
& M_{i}=\frac{1}{2} \times(\text { skor maksimal ideal }+ \text { skor minimal ideal }) \\
& M_{i}=\frac{1}{2} \times(100+60) \\
& M_{i}=80 \\
& S D i=\frac{1}{6} \times(\text { skor maksimal ideal }- \text { skor minimal ideal }) \\
& S D i=\frac{1}{6} \times(100-60) \\
& S D i=6,67
\end{aligned}
$$

Untuk kategori hasil belajar matematika siswa dan kriteria hasi belaja matematka untk tiap-tiap jenis pola asuh, dapat dlihat pada tabel di bawah ini.

Tabel 1 Kategori Hasil Belajar Matematika

\begin{tabular}{ccc}
\hline Interval Skor & Hasil & Kategori \\
\hline$X \leq M i-1,5 S D i$ & $X \leq 70$ & Sangat rendah \\
$M i-1,5 S D i<X \leq M i-0,5 S D i$ & $70<X \leq 77$ & Rendah \\
$M i-0,5 S D i<X \leq M i+0,5 S D i$ & $77<X \leq 83$ & Sedang \\
$M i+0,5 S D i<X \leq M i+1,5 S D i$ & $83<X \leq 90$ & Tinggi \\
$X>M i+1,5 S D i$ & $X>90$ & Sangat tinggi \\
\hline
\end{tabular}

Sebelum melakukan uji statistik inferensial, terlebih dahulu dilakukan uji asumsi normalitas dan linieritas. Setelah uji asumsi terpenuhi maka dianjutkan dengan uji statistik inferensial, yaitu analisis regresi sederhana,dengan menentuka persamaan regresi menggunakan rumus:

$$
\begin{gathered}
Y=a+b X \\
a=\frac{\left(\sum Y\right)\left(\sum X^{2}\right)-\left(\sum X\right)\left(\sum X Y\right)}{n\left(\sum X^{2}\right)-\left(\sum X\right)^{2}}
\end{gathered}
$$




$$
b=\frac{n\left(\sum X Y\right)-\left(\sum X\right)\left(\sum Y\right)}{n\left(\sum X^{2}\right)-\left(\sum X\right)^{2}}
$$

Keterangan:

$Y=$ Hasil belajar matematika siswa

$X=$ Pola asuh orang tua

$n=$ Banyak responden

(Siregar, 2017)

Kemudian untuk menentukan jenis pola asuh mana yang berpengaruh terhadap hasil belajar matematika siswa, dilakukan uji $t$ yang terlebih dahulu menentukan nilai $r$ dengan menggunakan rumus :

$$
\begin{gathered}
t_{\text {hitung }}=\frac{r \sqrt{n-2}}{\sqrt{1-(r)^{2}}} \\
r=\frac{n\left(\sum X Y\right)-\left(\sum X\right)\left(\sum Y\right)}{\sqrt{N\left\{\sum X^{2}-\left(\sum X\right)^{2}\right\} \cdot\left\{N \sum Y^{2}-\sum X^{2}-\left(\sum Y\right)^{2}\right\}}}
\end{gathered}
$$

Keterangan:

$r=$ korelasi parsial

$n=$ jumlah sampel

Jenis pola asuh dikatakan berpengaruh terhadap hasil belajar matematika siswa, apabila nilai $t_{\text {hitung }}>t_{\text {tabel }}$.

\begin{tabular}{|c|c|c|c|c|c|c|c|c|c|c|c|}
\hline \multirow{3}{*}{$\begin{array}{l}\text { Tipe Pola } \\
\text { Asuh }\end{array}$} & \multirow{3}{*}{$\begin{array}{c}\text { Banyak } \\
\text { Siswa }\end{array}$} & \multicolumn{10}{|c|}{ Kriteria Hasil Belajar } \\
\hline & & \multicolumn{2}{|c|}{$\begin{array}{l}\text { Sangat } \\
\text { Rendah }\end{array}$} & \multicolumn{2}{|c|}{ Rendah } & \multicolumn{2}{|c|}{ Sedang } & \multicolumn{2}{|c|}{ Tinggi } & \multicolumn{2}{|c|}{$\begin{array}{l}\text { Sangat } \\
\text { Tinggi }\end{array}$} \\
\hline & & $\mathrm{F}$ & $\%$ & $\mathrm{~F}$ & $\%$ & $\mathrm{~F}$ & $\%$ & $\mathrm{~F}$ & $\%$ & $\mathrm{~F}$ & $\%$ \\
\hline Otoriter & 12 & 10 & 83 & 2 & 17 & 0 & 0 & 0 & 0 & 0 & 0 \\
\hline Permissif & 44 & 37 & 84 & 6 & 24 & 1 & 2 & 0 & 0 & 0 & 0 \\
\hline Autoritatif & 75 & 61 & 81 & 10 & 13 & 4 & 5 & 0 & 0 & 0 & 0 \\
\hline
\end{tabular}

\section{HASIL DAN PEMBAHASAN}

Tabel 2 Kriteria Hasil Belajar Matematika Siswa Kelas XI SMK Negeri 3 Mataram

Keterangan : $\mathrm{F}=$ banyak siswa (frekuensi)

Tabel 3 Persamaan Regresi Linear Masing-Masing Jenis Pola Asuh Orang Tua terhadap Hasil Belajar Matematika

\begin{tabular}{cccc}
\hline No & Jenis Pola Asuh & Banyak Siswa & Persamaan Regresi \\
\hline 1 & Otoriter & 12 & $Y=31,95+2,45 X$ \\
2 & Permissif & 44 & $Y=69,30-1,31 X$ \\
3 & Autoritatif & 75 & $Y=25,21+3,02 X$ \\
\hline
\end{tabular}


Tabel 4 Nilai korelasi parsial $(r)$ dan nilai $t$ Data Hasil Penelitian

\begin{tabular}{clcccc}
\hline No & $\begin{array}{c}\text { Jenis Pola } \\
\text { Asuh }\end{array}$ & $\begin{array}{c}\text { Banyak } \\
\text { Siswa }\end{array}$ & $\begin{array}{c}\text { Nilai } \\
r\end{array}$ & $t_{\text {hitung }}$ & $t_{\text {tabel }}$ \\
\hline 1 & Otoriter & 12 & 0,27 & 0,89 & 2,22 \\
2 & Permissif & 44 & $-0,14$ & $-0,91$ & 2,02 \\
3 & Autoritatif & 75 & 0,39 & 3,6 & 1,99 \\
\hline
\end{tabular}

Dari tabel 2, yaitu tabel kriteria hasil belajar matematika siswa kelas XI SMK Negeri 3 Mataram, dapat disimpulkan bahwa hasil belajar matematika siswa untuk tiap-tiap pola asuh, dengan persentase tertinggi berada pada kategori sangat rendah, yaitu 83\% untuk siswa dengan pola asuh otoriter, 84\% untuk siswa dengan tipe pola asuh permissif, dan 81\% untuk siswa dengan tipe pola asuh autoritatif. Dari persentase tersebut, dapat diketahui bahwa sebagian besar siswa untuk tiap-tiap pola asuh, hasil belajarnya berada pada kategori sangat rendah.

Selain dilakukan analisis deskriptif terhadap data hasil penelitian, peneliti menggunakan teknik analsis regresi linear sederhana, dan $u j i-t$ untuk mengetahui apakah pola asuh orang tua berpengaruh secara signifikan atau tidak terhadap hasil belajar matematika siswa., yang dapat dilihat pada tabel berikut.

Berdasarkan tabel 4, dapat dilihat nilai $t$ hitung dan nilai $t$ tabel untuk tiap-tiap jenis pola asuh, sehingga dapat diketahui bahwa pola asuh orang tua yang berpengaruh terhadap hasil belajar matematika siswa adalah pola asuh autoritatif. Sedangkan, pola asuh otoriter dan pola asuh permissif tidak berpengaruh terhadap hasil belajar matematika siswa. Berpengaruh atau tidaknya tiap-tiap jenis pola asuh terhadap hasil belajar matematika, didasarkan dengan pengambilan keputusan, yaitu jika nilai dari $t$ hitung lebih besar daripada nilai $t$ tabel, maka pola asuh tersebut berpengaruh terhadap hasil belajar matematika siswa.

Berdasarkan tabel 3, dapat dilihat hubungan antara pola asuh autoritatif dengan hasil belajar matematika siswa. Setiap 1 peningkatan nilai pada pola asuh orang tua hasil belajar akan meningkat sebesar 3,02. Sehingga dapat disimpulkan bahwa pola asuh autoritatif berpengaruh secara signifikan terhadap hasil belajar matematika siswa kelas XI SMK Negeri 3 Mataram, Tahun Pelajaran 2019/2020, dengan besar pengaruh adalah $15,32 \%$.

Pola asuh autoritatif (demokratis) adalah pola asuh yang memperhatikan dan menghargai kebebasan anak yang tidak mutlak, dengan bimbingan yang penuh pengertian antara anak dan orang tua, memberi penjelasan secara rasional dan objektif jika keinginan dan pendapat anak tidak sesuai. Sehingga, dalam pola asuh ini anak tumbuh dengan rasa tanggung jawab, serta mampu bertindak sesuai dengan norma yang ada (Adawiah, 2017). Pada pola asuh autoritatif, ada kerjasama antara orang tua dan anak, anak diakui sebagai pribadi, ada bimbingan dan pengarahan dari orang tua, dan ada kontrol dari orang tua yang tidak keras (Tridhonanto, 2014). Karena adanya 
komunikasi dua arah yang memberikan ruang untuk anak mengeluarkan pendapat, anak juga diakui sebagai pribadi serta adanya bimbingan dan pengarahan dari orang tuanya, anak yang diasuh dengan pola asuh autoritatif, akan menjadi lebih demokratis, lebih bertanggung jawab, percaya diri, dan pandai beradaptasi.

Selain pola asuh autoritatif, pola asuh yang sering diterapkan oleh orang tua terhadap anaknya adalah pola asuh otoriter dan pola asuh permissif, tetapi dua pola asuh tersebut tidak berpengaruh terhadap hasil belajar matematika siswa. Pola asuh otoriter yaitu pola asuh dimana orang tua menerapkan aturan dan batasan yang mutlak harus ditaati, tanpa memberi kesempatan pada anak untuk berpendapat, jika anak tidak mematuhi akan diancam dan dihukum (Adawiah, 2017). Dalam pola asuh otoriter, kebebasan orang tua dominan, anak tidak diakui sebagai pribadi, kontrol terhadap tingkah laku anak sangat ketat, dan orang tua menghukum anak jika anak tidak patuh (Tridhonanto, 2014). Anak yang diasuh dengan pola asuh otoriter, akan merasa rendah diri, kurang percaya diri, dan cenderung tertutup karena dia beranggapan bahwa orang sekelilingnya tidak mau mendengarkannya sehingga anak lebih memilih untuk diam dan tertutup. Selain pola asuh otoriter, ada pola asuh permissif, yaitu pola asuh yang dapat diartikan sebagai perilaku orang tua membebaskan anaknya untuk melakukan apa yang diinginkan tanpa mempertanyakan. Pola asuh ini tidak menggunakan aturan-aturan yang ketat bahkan bimbingan pun kurang diberikan sehingga tidak ada pengendalian atau pengontrolan serta tuntutan kepada anak (Adawiah, 2017). Dalam pola asuh permissif, dominasi pada anak, sikap longgar dari orang tua, tidak ada bimbingan dan pengarahan dari orang tua, kontrol dan perhatian orang tua sangat kurang (Tridhonanto, 2014). Karena kontrol dan perhatian dari orang tua dengan pola asuh permissif sangat kurang serta lebih didominasi oleh anak, anak dengan pola asuh ini akan menjadi seseorang yang kurang bertanggung jawab, suka memberontak, manja, dan kurang bisa mengandalkan diri.

Berdasarkan hasil penelitian, penjelasan tiga tipe pola asuh, ciri-ciri dari tiap tipe pola asuh tersebut, serta dampak yang ditimbulkan dari penerapan tiap pola asuh, dapat dilihat bahwa pola asuh autoritatif merupakan pola asuh terbaik yang dapat diterapkan oleh orang tua terhadap anak-anaknya. Dalam pola asuh autoritatif juga ada bimbingan dan arahan serta kontrol yang tidak terlalu keras, artinya tidak terlalu mengekang dan mengharuskan anak megikuti kemauan orang tua walaupun tidak sesuai dengan kemampuannya. Selain itu, komunikasi yang terjadi adalah komunikasi dua arah antara anak dan orang tua. Sehingga bagaimana pun pendapat dan keputusan dari kedua belah pihak, dapat dibicarakan dan diputuskan bersama-sama, dan tidak ada pengambilan keputusan secara sepihak saja.

\section{SIMPULAN}

Pola asuh orang tua yang berpengaruh terhadap hasil belajar matematika siswa kelas XI SMK Negeri 3 Mataram Tahun Pelajaran 2019/2020 adalah pola asuh autoritatif, dengan besar pengaruh yaitu $15,32 \%$. 
Kriteria hasil belajar matematika siswa kelas XI SMK Negeri 3 Mataram Tahun Pelajaran 2019/2020 untuk jenis pola asuh otoriter berada pada kategori sangat rendah dan rendah. Untuk siswa dengan pola asuh permissif, hasil belajarnya berada pada kategori sangat rendah, rendah, dan sedang. Untuk siswa dengan tipe pola asuh autoritatif, hasil belajarnya berada pada kategori sangat rendah, rendah, dan sedang. Sebagian besar hasil belajar siswa untuk tiap-tiap pola asuh berada pada kategori sangat rendah.

\section{REKOMENDASI}

Diharapkan kepada orang tua agar menerapkan pola asuh autoritatif terhadap anakanaknya agar anak bisa menjadi pribadi yang lebih bertanggung jawab, lebih demokratis, lebih percaya diri dan pandai beradaptasi. Dengan demikian, anak akan lebih giat dalam belajar karena merasa memiliki tanggung jawab untuk membanggakan orang tua sehingga, sehingga mereka akan tetap berusaha agar mendapatkan hasil belajar yang lebih baik.

Untuk guru seharusnya lebih memperhatikan siswa dengan pola asuh otoriter dan permissive (karena siswa dengan pola asuh tersebut akan cenderung tertutup, tidak bertanggung jawab, serta kurang percaya diri, sehingga mereka merasa tidak peduli dengan hasil belajar yang mereka dapatkan), agar siswa tersebut juga bisa lebih giat dalam belajar sehingga mampu memperoleh hasil belajar yang lebih baik.

Untuk para siswa, janganlah takut berkomunikasi, baik dengan orang tua maupun guru. Ungkapkanlah setiap kesulitan yang dihadapi selama proses pembelajaran, agar hal tersebut tidak menjadi penghambat untuk memperoleh hasil belajar yang lebih baik.

\section{REFERENSI}

Adawiah, R. (2017). Dominasi Keluarga Dalam Meningkatkan Prestasi Belajar Pada Ranah Kognitif Afektif Dan Psikomotor. Jurnal Pendidikan Kewarganegaraan, 7(1), 33-48. https://doi.org/10.36088/palapa.v3i1.755

Dasmo. (2011). Pengaruh Tingkat Pendidikan dan Pola Asuh Orang Tua terhadap Prestasi Belajar IPA. Jurnal Formatif, 2(2), 132-139.

Gunarsa, S. (2006). Psikologi Perkembangan Anak dan Remaja. PT BPK Gunung Mulia.

Siregar, S. (2017). Metode Penelitian Kuantitatif (Dilengkapi dengan Perbandingan Perhitungan Manual dan SPSS). Prenadamedia Grup.

Slameto. (2015). Belajar dan Faktor-Faktor yang Mempengaruhinya. Rineka Cipta.

Tridhonanto, A. 1. (2014). Mengembangkan Pola Asuh Demokratis. Gramedia. 